\title{
KELAYAKAN LINGKUNGAN PERAIRAN UNTUK PENGEMBANGAN BUDIDAYA IKAN KERAPU DALAM KERAMBA JARING APUNG DI KABUPATEN SITUBONDO
}

\author{
Sri Sukari Agustina \\ Staf Pengajar Fakultas Perikanan UNISMUH Luwuk Kabupaten Banggai
}

\begin{abstract}
ABSTRAK
Penelitian ini bertujuan menelaah kelayakan lingkungan perairan untuk pengembangan budidaya ikan kerapu dalam keramba jaring apung di Kabupaten Situbondo yang produktif dan berkelanjutan melalui analisis kualitas perairan dan analisis indeks biologi fitoplankton. Metode penelitian adalah metode survei, sedangkan pengukuran dan pengamatan faktor biofisik perairan di lokasi penelitian dilakukan pada masing-masing lokasi budidaya ikan kerapu dalam keramba jaring apung meliputi kecepatan arus, kecerahan perairan, kedalaman perairan, suhu permukaan laut (SPL), elevasi pasang surut, tinggi gelombang, $\mathrm{pH}$, salinitas, oksigen terlarut, BOD, amonia, nitrit, nitrat, fosfat, $\mathrm{H}_{2} \mathrm{~S}$ dan kelimpahan plankton. Hasil penelitian menunjukkan secara keseluruhan parameter kualitas air di perairan Klatakan Kecamatan Kendit Kabupaten Situbondo lebih layak untuk dijadikan lokasi pengembangan budidaya ikan kerapu dalam keramba jaring apung dibandingkan perairan Gelung Kecamatan Panarukan Kabupaten Situbondo.
\end{abstract}

Kata kunci: kerapu, keramba jaring apung, biofisik perairan, fitoplankton

\section{FEASIBILITY OF AQUATIC ENVIRONMENT FOR GROUPER CULTURE DEVELOPMENT IN THE FLOATING NET CAGE IN SITUBONDO REGENCY}

\begin{abstract}
This study aims to examine the feasibility of an aquatic environment for the development of grouper culture in floating net cages in Situbondo productive and sustainable through the analysis of water quality and analysis of biological indices of phytoplankton. The research method is the method of the survey, while the measurements and observations of biophysical factors waters at the site of research done on each site cultured grouper in floating net cages include current speed, the brightness of the waters, deep waters, sea surface temperature (SPL), tidal elevation, wave height, $\mathrm{pH}$, salinity, dissolved oxygen, BOD, ammonia, nitrite, nitrate, phosphate, $\mathrm{H} 2 \mathrm{~S}$ and abundance of plankton. The results indicate overall water quality parameters in the waters of District Klatakan gird Situbondo more suitable as the location of the development of grouper culture in floating net over the waters of District Panarukan Situbondo Regency.
\end{abstract}

Key words: grouper, floating net cage, biophysical waters, phytoplankton 


\section{PENDAHULUAN}

Kabupaten Situbondo memiliki panjang $\pm 150 \mathrm{~km}$ dari barat ke timur sepanjang pantai Selat Madura dan kedalaman wilayahnya dari pantai rata-rata $11 \mathrm{~m}$, secara geografis sangat potensial untuk pengembangan budidaya ikan kerapu. Potensi budidaya ikan kerapu dalam keramba jaring apung yang ada di Kabupaten Situbondo belum dimanfaatkan dan ditangani secara optimal dibandingkan dengan luas wilayahnya, sebagai gambaran diperoleh data terjadinya penurunan volume produksi ikan kerapu dengan keramba jaring apung di Kabupaten Situbondo pada tahun 2006 sebesar 125,22 ton, pada tahun 2007 sebesar 93,94 ton dan pada tahun 2008 sebesar 5,20 ton (Dinas Kelautan dan Perikanan Kabupaten Situbondo, 2007-2009). Volume produksi ikan kerapu menurun disebabkan beberapa permasalahan antara lain terjadinya penurunan kelayakan lingkungan untuk usaha budidaya ikan kerapu.

Kelayakan lingkungan untuk usaha budidaya dapat diestimasi melalui pengukuran kuantitatif dan kualitatif terhadap biota yang menghuni perairan tersebut. Satu di antara biota yang sering digunakan dalam keperluan ini adalah plankton karena studi ekologinya murah dalam biaya, mudah dalam pelaksanaan dan efektif dalam hasil yang diperoleh.

Keragaman jenis merupakan parameter yang digunakan dalam mengetahui suatu komunitas. Parameter ini mencirikan kekayaan jenis dan keseimbangan dalam suatu komunitas, akhir-akhir ini terjadi penurunan yang menjadikan keragaman fitoplankton rendah. Ekosistem dengan keragaman rendah adalah tidak stabil dan rentan terhadap pengaruh tekanan dari luar dibandingkan dengan ekosistem yang memiliki keragaman tinggi (Boyd, 1999). Fitoplankton selain berfungsi dalam keseimbangan ekosistem perairan budidaya, juga berfungsi sebagai pakan alami di dalam usaha budidaya.

Tujuan penelitian adalah menelaah kelayakan lingkungan perairan untuk pengembangan budidaya ikan kerapu dalam keramba jaring apung di Kabupaten Situbondo yang produktif dan berkelanjutan melalui analisis kualitas perairan dan analisis indeks biologi fitoplankton.

\section{METODOLOGI PENELITIAN}

Penelitian ini dilaksanakan pada bulan Pebruari 2009 sampai dengan bulan April 2009 dengan lokasi penelitian wilayah perairan Klatakan Kecamatan Kendit dan perairan Gelung Kecamatan Panarukan Kabupaten Situbondo. Analisis parameter kualitas air dilaksanakan di Laboratorium BBAP Situbondo.

Metode yang digunakan dalam pengambilan data adalah metode survei. Pengambilan sampel air di lokasi penelitian dilakukan di 4 titik pada masing-masing lokasi budidaya ikan kerapu dalam keramba jarring apung. Pengukuran dan pengamatan faktor biofisik perairan meliputi kecepatan arus, kecerahan perairan, kedalaman perairan, suhu permukaan laut (SPL), elevasi pasang surut, tinggi gelombang, $\mathrm{pH}$, salinitas, oksigen terlarut, BOD, amonia, nitrit, nitrat, fosfat, $\mathrm{H}_{2} \mathrm{~S}$ dan kelimpahan plankton. 
Di setiap stasiun penelitian, fitoplankton dikoleksi menggunakan plankton net no. 25. Sampel fitoplankton yang diperoleh diidentifikasi jenis fitoplankton dengan bantuan mikroskop berpedoman pada Newel dan Newel (1977), serta Yamaji (1976). Kelimpahannya dihitung menggunakan rumus counting cell (APHA, 1998). Analisis kuantitatif indeks biologi fitoplankton meliputi perhitungan keragaman, keseragaman dan dominansi dari Shannon-Wiener (Odum,1971; Basmi, 2000). Perbedaan kelimpahan, keragaman, keseragaman dan dominansi fitoplankton dianalisis secara deskriptif.
Indeks keseragaman:

$\mathrm{E} \quad=\mathrm{H}^{\prime} /$ Hmaks

$\mathrm{E} \quad=$ Indeks keseragaman jenis

$\mathrm{H}^{\prime} \quad=$ Indeks keragaman jenis

Hmaks $=$ Indeks keragaman maksimum

\section{Indeks dominansi:}

$\mathrm{D}=(\mathrm{Pi})^{2}$

$\mathrm{D}=$ Indeks Dominansi

ni $=$ Jumlah individu taksa ke-i

$\mathrm{N}=$ Jumlah total individu

$\mathrm{Pi}=\mathrm{ni} / \mathrm{N}=$ Proporsi spesies ke-i

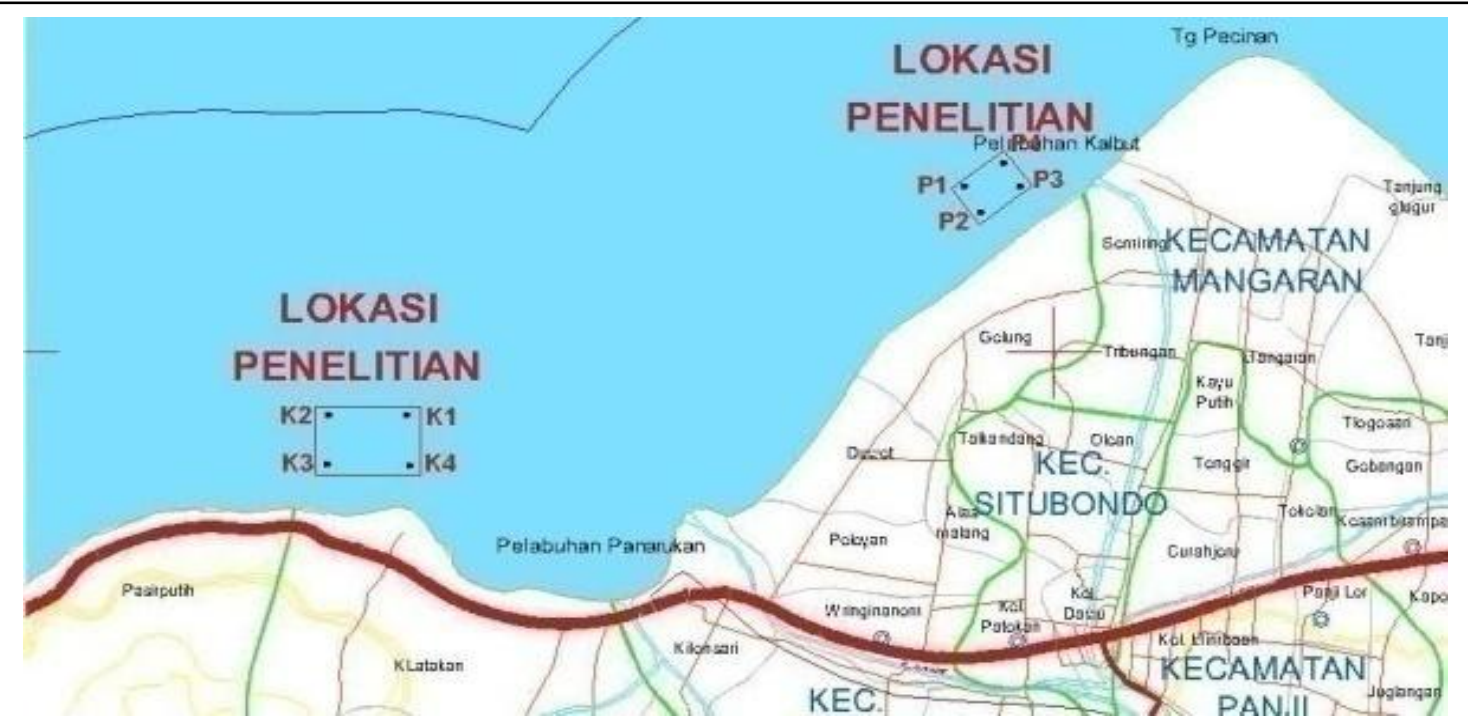

Gambar : Lokasi penelitian di perairan Klatakan dan perairan Gelung Kabupaten Situbondo Keterangan: K 1 s.d. K4 dan P1 s.d. P4 merupakan titik-titik sampling penelitian

\section{Indeks keanekaragaman jenis:}

$\mathrm{H}^{\prime}=-\mathrm{Pi} \ln \mathrm{Pi} ; \quad \mathrm{Pi}=\mathrm{ni} / \mathrm{N}$

$\mathrm{H}^{\prime}=$ Indeks keragaman jenis

ni $=$ Jumlah individu taksa ke-i

$\mathrm{N}=$ Jumlah total individu

$\mathrm{Pi}=$ Proporsi spesies ke-i

\section{HASIL DAN PEMBAHASAN}

\section{Parameter Fisika}

Pengukuran parameter fisika pada saat penelitian didapatkan nilai rata-rata hasil pengamatan pada masing-masing stasiun (lokasi penelitian) diperlihatkan pada Tabel 1 dan Tabel 2. 
Tabel 1.

Rata-rata hasil pengamatan dan pengukuran parameter fisika pada masing-masing stasiun di perairan Klatakan Kecamatan Kendit selama penelitian

\begin{tabular}{|c|c|c|c|c|c|c|c|c|}
\hline \multirow{3}{*}{ No } & \multirow{3}{*}{ Variabel } & \multirow{3}{*}{ Satuan } & \multirow{2}{*}{\multicolumn{4}{|c|}{$\begin{array}{c}\text { Stasiun (Lokasi Penelitian) } \\
\text { Perairan Klatakan, } \\
\text { Kecamatan Kendit }\end{array}$}} & \multirow{3}{*}{ Rekomendasi } & \multirow{3}{*}{ Pustaka } \\
\hline & & & & & & & & \\
\hline & & & $\mathrm{K}_{1}$ & $\mathrm{~K}_{2}$ & $\mathrm{~K}_{3}$ & $\mathrm{~K}_{4}$ & & \\
\hline 1 & Kecepatan arus & $\mathrm{m} / \mathrm{detik}$ & 0,15 & 0,15 & 0,15 & 0,15 & $0,15-0,30$ & Akbar dan Sudaryanto (2002) \\
\hline 2 & Kecerahan & meter & 4 & 4 & 4 & 4 & $>3$ & Sudradjat (2008) \\
\hline 3 & Kedalaman & meter & 13,5 & 13,5 & 15 & 15 & $7-15$ & Ditjen Perikanan Budidaya (2005) \\
\hline 4 & Suhu & ${ }^{0} \mathrm{C}$ & 30 & 30 & 30 & 30 & $26-32$ & Ditjen Perikanan Budidaya (2005) \\
\hline 5 & Elevasi Pasang Surut * & meter & 2 & 2 & 2 & 2 & $<1$ & Dwiyanto \& Suriawan (2006) \\
\hline 6 & Tinggi Gelombang * & meter & 1,33 & 1,33 & 1,33 & 1,33 & $<0,5$ & Dwiyanto \& Suriawan (2006) \\
\hline
\end{tabular}

Tabel 2.

Rata-rata hasil pengamatan dan pengukuran parameter fisika pada masing-masing stasiun di perairan Gelung Kecamatan Panarukan selama penelitian

\begin{tabular}{|c|c|c|c|c|c|c|c|c|}
\hline \multirow{3}{*}{ No } & \multirow{3}{*}{ Variabel } & \multirow{3}{*}{ Satuan } & \multirow{2}{*}{\multicolumn{4}{|c|}{$\begin{array}{c}\text { Stasiun (Lokasi Penelitian) } \\
\text { Perairan Gelung, } \\
\text { Kecamatan Panarukan } \\
\end{array}$}} & \multirow{3}{*}{ Rekomendasi } & \multirow{3}{*}{ Pustaka } \\
\hline & & & & & & & & \\
\hline & & & $\mathrm{P}_{1}$ & $\mathrm{P}_{2}$ & $\mathrm{P}_{3}$ & $\mathrm{P}_{4}$ & & \\
\hline 1 & Kecepatan arus & $\mathrm{m} /$ detik & 0,25 & 0,24 & 0,20 & 0,20 & $0,15-0,30$ & Akbar dan Sudaryanto (2002) \\
\hline 2 & Kecerahan & meter & 2 & 2 & 2 & 2 & $>3$ & Sudradjat (2008) \\
\hline 3 & Kedalaman & meter & 7 & 7 & 7 & 7 & $7-15$ & Ditjen Perikanan Budidaya (2005) \\
\hline 4 & Suhu & ${ }^{0} \mathrm{C}$ & 30 & 30 & 30 & 30 & $26-32$ & Ditjen Perikanan Budidaya (2005) \\
\hline 5 & Elevasi Pasang Surut* & meter & 1,7 & 1,7 & 1,7 & 1,7 & $<1$ & Dwiyanto \& Suriawan (2006) \\
\hline 6 & Tinggi Gelombang * & meter & 1,33 & 1,33 & 1,33 & 1,33 & $<0,5$ & Dwiyanto \& Suriawan (2006) \\
\hline
\end{tabular}

Hasil analisis pada Tabel 1 dan Tabel 2 di atas, menunjukkan bahwa variabel kecepatan arus, kedalaman perairan, dan suhu di wilayah perairan Klatakan Kecamatan Kendit dan perairan Gelung Kecamatan Panarukan Kabupaten Situbondo berdasarkan kriteria Akbar dan Sudaryanto (2002), Sudradjat (2008) dan Ditjen Perikanan Budidaya (2005) berada pada kisaran yang layak untuk dijadikan lokasi budidaya ikan kerapu dalam keramba jaring apung. Kecerahan perairan untuk wilayah perairan Klatakan Kecamatan Kendit masih berada pada kisaran yang layak yaitu lebih dari $3 \mathrm{~m}$ (Sudradjat, 2008) dan untuk wilayah perairan Gelung Kecamatan Panarukan dibawah batas minimal yang disarankan untuk lokasi budidaya ikan kerapu dalam keramba jaring apung yaitu kurang dari 3 m. Nilai kecerahan perairan Gelung di bawah batas minimal disebabkan beberapa faktor antara lain: 1) tingginya bahan organik dan bahan anorganik baik 
tersuspensi maupun terlarut seperti lumpur, pasir halus, plankton dan mikroorganisme lainnya; 2) kurang terjaganya kebersihan keramba di lokasi budidaya; dan 3) kedalaman perairan Gelung Kecamatan Panarukan yang lebih dangkal dibandingkan kedalaman perairan Klatakan Kecamatan Kendit. Ditjen Perikanan Budidaya (2005), menyatakan kecerahan perairan merupakan salah satu indikator dalam penentuan lokasi budidaya ikan kerapu dengan keramba jaring apung, perairan dengan tingkat kecerahan sangat rendah menandakan bahan organik terlarut sangat tinggi yang berarti perairan tersebut cukup subur dan tidak baik digunakan untuk lokasi budidaya ikan kerapu dalam keramba jaring apung.

Hasil analisis elevasi pasang surut dan tinggi gelombang wilayah perairan Klatakan Kecamatan Kendit dan perairan Gelung Kecamatan Panarukan berdasarkan kriteria Dwiyanto dan Suriawan (2008) berada di atas batas maksimal yang disarankan untuk lokasi budidaya kerapu di keramba jaring apung. Perairan Klatakan Kecamatan Kendit dan perairan gelung Kecamatan Panarukan Kabupaten Situbondo secara umum merupakan perairan yang di musimmusim tertentu akan mengalami terpaan gelombang yang cukup besar. Terjadinya gelombang besar biasanya pada musim selatan (musim barat) antara bulan Nopember sampai dengan bulan Maret, dimana gelombang yang timbul bisa mencapai ketinggian maksimal. Keberadaaan terumbu karang di sekitar lokasi budidaya keramba jaring apung perairan Klatakan Kecamatan Kendit dan perairan Gelung Kecamatan Panarukan merupakan salah satu faktor pelindung dari hempasan gelombang secara langsung (LAPAN, 2004).

\section{Parameter Kimia}

Pengukuran parameter kimia pada saat penelitian didapatkan nilai rata-rata hasil pengamatan pada masing-masing stasiun (lokasi penelitian) diperlihatkan pada Tabel 3 dan Tabel 4. 
Tabel 3.

Rata-rata hasil pengamatan dan pengukuran parameter kimia pada masing-masing stasiun di perairan Klatakan Kecamatan Kendit selama penelitian

\begin{tabular}{|c|c|c|c|c|c|c|c|c|}
\hline \multirow{3}{*}{ No } & \multirow{3}{*}{ Variabel } & \multirow{3}{*}{ Satuan } & \multicolumn{4}{|c|}{ Stasiun (Lokasi Penelitian) } & \multirow{3}{*}{$\begin{array}{l}\text { Rekomen- } \\
\text { dasi }\end{array}$} & \multirow{3}{*}{ Pustaka } \\
\hline & & & \multicolumn{4}{|c|}{$\begin{array}{l}\text { Perairan Klatakan, } \\
\text { Kecamatan Kendit }\end{array}$} & & \\
\hline & & & $\mathrm{K}_{1}$ & $\mathrm{~K}_{2}$ & $\mathrm{~K}_{3}$ & $\mathrm{~K}_{4}$ & & \\
\hline 1 & $\mathrm{pH}$ & & 8,27 & 8,26 & 8,25 & 8,23 & $7-8,5$ & KEPMEN LH No. 51 Tahun 2004 \\
\hline 2 & Salinitas & ppt & 31,5 & 31,5 & 31,5 & 31,5 & $30-34$ & Dwiyanto \& Suriawan (2006) \\
\hline 3 & Oksigen terlarut & $\mathrm{mg} / \mathrm{L}$ & 5,26 & 5,26 & 5,26 & 4,8 & $4-8$ & Sudradjat (2008) \\
\hline 4 & BOD & $\mathrm{mg} / \mathrm{L}$ & 3,24 & 1,21 & 1,21 & 1,56 & 20 & KEPMEN LH No. 51 Tahun 2004 \\
\hline 5 & Amonia & $\mathrm{mg} / \mathrm{L}$ & $<0,001$ & $<$ & $\underset{0,001}{<}$ & $\begin{array}{c}< \\
0,001\end{array}$ & $<0,02$ & Sudradjat (2008) \\
\hline 6 & Nitrit & $\mathrm{mg} / \mathrm{L}$ & $<0,001$ & $<$ & $\stackrel{<}{<}$ & $\begin{array}{c}< \\
0,001\end{array}$ & $<0,05$ & Sudradjat (2008) \\
\hline 7 & Nitrat & $\mathrm{mg} / \mathrm{L}$ & $<0,001$ & $<$ & $\begin{array}{c}< \\
0,001\end{array}$ & $\begin{array}{c}< \\
0,001\end{array}$ & 0,008 & KEPMEN LH No. 51 Tahun 2004 \\
\hline 8 & Fosfat & $\mathrm{mg} / \mathrm{L}$ & $<0,001$ & $\begin{array}{c}< \\
0,001\end{array}$ & $\underset{0,001}{<}$ & $\begin{array}{c}< \\
0,001\end{array}$ & 0,015 & KEPMEN LH No. 51 Tahun 2004 \\
\hline 9 & $\mathrm{H}_{2} \mathrm{~S}$ & $\mathrm{mg} / \mathrm{L}$ & 0,01 & 0 & 0 & 0 & 0,01 & KEPMEN LH No. 51 Tahun 2004 \\
\hline
\end{tabular}

Tabel 4.

Rata-rata hasil pengamatan dan pengukuran parameter kimia pada masing-masing stasiun di perairan Gelung Kecamatan Panarukan selama penelitian

\begin{tabular}{|c|c|c|c|c|c|c|c|c|}
\hline \multirow{3}{*}{ No } & \multirow{3}{*}{ Variabel } & \multirow{3}{*}{ Satuan } & \multirow{2}{*}{\multicolumn{4}{|c|}{$\begin{array}{c}\text { Stasiun (Lokasi Penelitian) } \\
\text { Perairan Gelung, } \\
\text { Kecamatan Panarukan }\end{array}$}} & \multirow{3}{*}{$\begin{array}{l}\text { Rekomen- } \\
\text { dasi }\end{array}$} & \multirow{3}{*}{ Pustaka } \\
\hline & & & & & & & & \\
\hline & & & $\mathrm{P}_{1}$ & $\mathrm{P}_{2}$ & $\mathrm{P}_{3}$ & $\mathrm{P}_{4}$ & & \\
\hline 1 & $\mathrm{pH}$ & & 8,27 & 8,28 & 8,29 & 8,19 & $7-8,5$ & KEPMEN LH No. 51 Tahun 2004 \\
\hline 2 & Salinitas & ppt & 32,5 & 31 & 31,5 & 31,5 & $30-34$ & Dwiyanto \& Suriawan (2006) \\
\hline 3 & $\begin{array}{l}\text { Oksigen } \\
\text { Terlarut }\end{array}$ & $\mathrm{mg} / \mathrm{L}$ & 4,8 & 5,26 & 5,26 & 4,8 & $4-8$ & Sudradjat (2008) \\
\hline 4 & BOD & $\mathrm{mg} / \mathrm{L}$ & 1,97 & 1,62 & 3,24 & 1,56 & 20 & KEPMEN LH No. 51 Tahun 2004 \\
\hline 5 & Amonia & $\mathrm{mg} / \mathrm{L}$ & $<0,001$ & $<0,001$ & $<0,001$ & $<0,001$ & $<0,02$ & Sudradjat (2008) \\
\hline 6 & Nitrit & $\mathrm{mg} / \mathrm{L}$ & $<0,001$ & $<0,001$ & $<0,001$ & $<0,001$ & $<0,05$ & Sudradjat (2008) \\
\hline 7 & Nitrat & $\mathrm{mg} / \mathrm{L}$ & $<0,001$ & $<0,001$ & $<0,001$ & $<0,001$ & 0,008 & KEPMEN LH No. 51 Tahun 2004 \\
\hline 8 & Fosfat & $\mathrm{mg} / \mathrm{L}$ & $<0,001$ & $<0,001$ & $<0,001$ & $<0,001$ & 0,015 & KEPMEN LH No. 51 Tahun 2004 \\
\hline 9 & $\mathrm{H}_{2} \mathrm{~S}$ & $\mathrm{mg} / \mathrm{L}$ & 0,01 & 0,02 & 0,02 & 0,02 & 0,01 & KEPMEN LH No. 51 Tahun 2004 \\
\hline
\end{tabular}

Hasil analisis parameter kimia pada Tabel 3 dan tabel 4 menunjukkan bahwa variabel $\mathrm{pH}$, salinitas, oksigen terlarut, BOD, amonia, nitrit, nitrat, dan fosfat di wilayah perairan Klatakan Kecamatan Kendit dan perairan Gelung Kecamatan Panarukan Kabupaten
Situbondo berdasarkan kriteria KEPMEN LH No. 51 Tahun 2004, Dwiyanto \& Suriawan (2006) dan Sudradjat (2008) berada pada kisaran yang layak untuk dijadikan lokasi budidaya ikan kerapu dalam keramba jaring apung, sementara $\mathrm{H}_{2} \mathrm{~S}$ untuk wilayah perairan Klatakan 
Kecamatan Kendit masih berada pada kisaran yang layak yaitu $0,01 \mathrm{mg} / \mathrm{L}$ (KEPMEN LH No. 51 Tahun 2004) dan untuk wilayah perairan Gelung Kecamatan Panarukan di atas batas maksimal yang disarankan untuk lokasi budidaya ikan kerapu dalam keramba jaring apung yaitu lebih dari $0,01 \mathrm{mg} / \mathrm{L}$.

Kedalaman perairan di perairan Gelung Kecamatan Panarukan yang relatif dangkal $(7 \mathrm{~m})$ menyebabkan proses sirkulasi air tidak terjadi secara maksimal terutama di dasar perairan. Hal ini diperkuat oleh Hanggono (2007) yang menyatakan bahwa pembusukan bahanbahan organik yang ada di dasar perairan terakumulasi di kolom air yang menyebabkan tingginya kandungan $\mathrm{H}_{2} \mathrm{~S}$. Jika hal ini terjadi, maka keramba jaring apung tersebut harus dipindahkan ke dalam lokasi yang kedalaman airnya lebih dalam.

\section{Parameter Biologi}

Jumlah individu dan spesies serta indeks keanekaragaman, kemerataan, dan dominansi fitoplankton di perairan Klatakan Kecamatan Kendit dan perairan Gelung Kecamatan Panarukan Kabupaten Situbondo diperlihatkan pada Tabel 5 dan Tabel 6.

Tabel 5.

Hasil pengamatan fitoplankton lokasi perairan Klatakan Kecamatan Kendit Kabupaten Situbondo

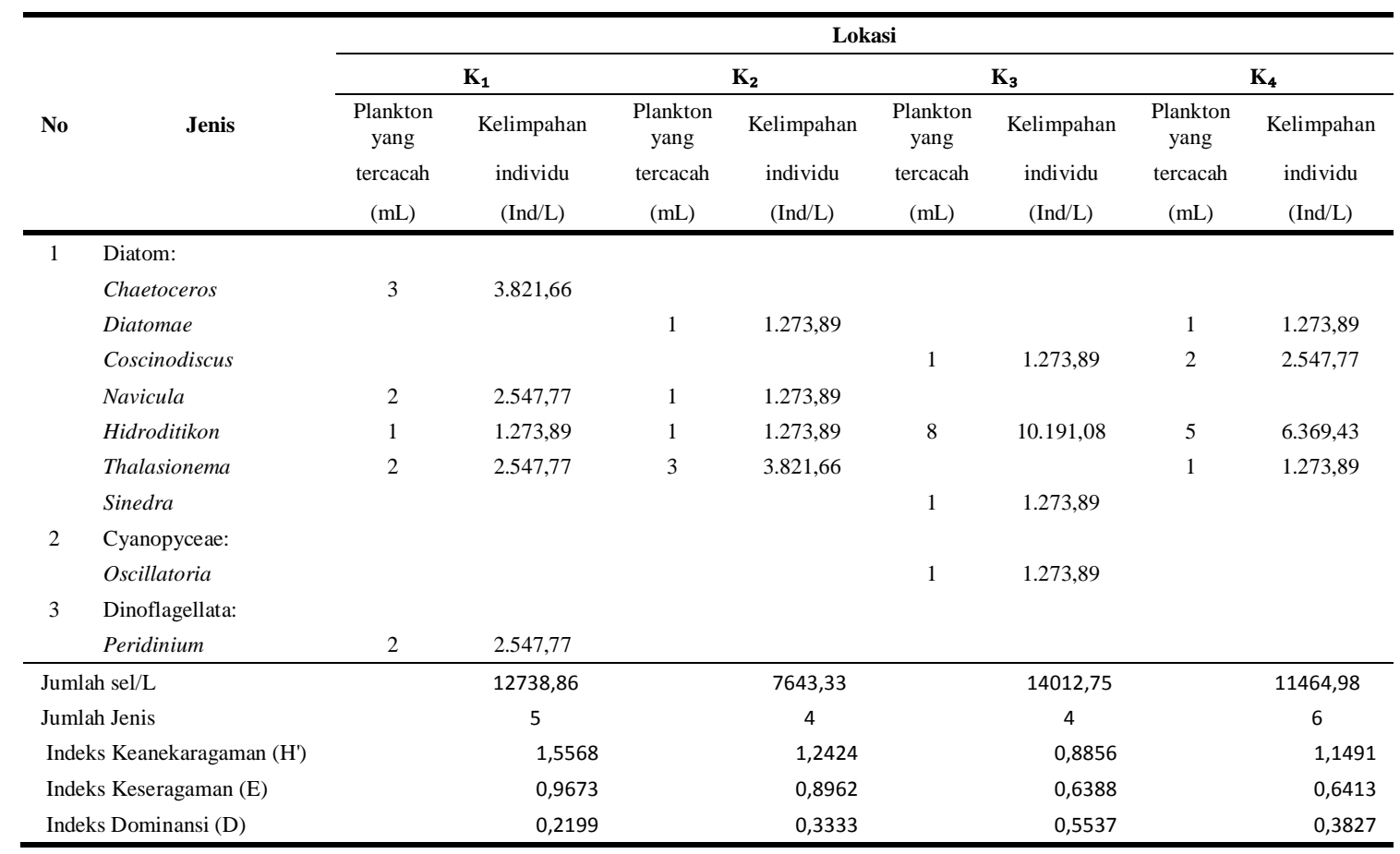

Sumber : Laboratorium Penguji BBAP Situbondo (2009) 
Tabel 6.

Hasil pengamatan fitoplankton lokasi perairan Gelung Kecamatan Panarukan Kabupaten Situbondo

\begin{tabular}{|c|c|c|c|c|c|c|c|c|c|}
\hline \multirow[b]{3}{*}{ No } & \multirow[b]{3}{*}{ Jenis } & \multicolumn{8}{|c|}{ Stasiun (Lokasi penelitian) } \\
\hline & & \multicolumn{2}{|c|}{$\mathbf{P}_{1}$} & \multicolumn{2}{|c|}{$\mathbf{P}_{2}$} & \multicolumn{2}{|c|}{$\mathbf{P}_{3}$} & \multicolumn{2}{|c|}{$\mathbf{P}_{4}$} \\
\hline & & $\begin{array}{l}\text { Plankton } \\
\text { yang } \\
\text { tercacah } \\
(\mathrm{mL})\end{array}$ & $\begin{array}{c}\text { Kelimpahan } \\
\text { individu } \\
\text { (Ind/L) }\end{array}$ & $\begin{array}{l}\text { Plankton } \\
\text { yang } \\
\text { tercacah } \\
\text { (mL) }\end{array}$ & $\begin{array}{c}\text { Kelimpahan } \\
\text { individu } \\
\text { (Ind/L) }\end{array}$ & $\begin{array}{l}\text { Plankton } \\
\text { yang } \\
\text { tercacah } \\
(\mathrm{mL})\end{array}$ & $\begin{array}{c}\text { Kelimpahan } \\
\text { individu } \\
\text { (Ind/L) }\end{array}$ & $\begin{array}{l}\text { Plankton } \\
\text { yang } \\
\text { tercacah } \\
(\mathrm{mL})\end{array}$ & $\begin{array}{c}\text { Kelimpahan } \\
\text { individu } \\
\text { (Ind/L) }\end{array}$ \\
\hline \multirow[t]{7}{*}{1} & Diatom: & & & & & & & & \\
\hline & Diatomae & 4 & $5.095,54$ & 2 & $2.547,77$ & & & & \\
\hline & Coscinodiscus & & & 1 & $1.273,89$ & & & 4 & $5.095,54$ \\
\hline & Nitzchia & & & 3 & $3.821,66$ & & & & \\
\hline & Navicula & 2 & $2.547,77$ & 2 & $2.547,77$ & 2 & $2.547,77$ & 2 & $2.547,77$ \\
\hline & Hidroditikon & 3 & $3.821,66$ & 1 & $1.273,89$ & 1 & $1.273,89$ & 4 & $5.095,54$ \\
\hline & Thalasionema & 3 & $3.821,66$ & 17 & $21.656,05$ & 3 & $3.821,66$ & 1 & $1.273,89$ \\
\hline \multirow[t]{2}{*}{2} & Cyanopyceae: & & & & & & & & \\
\hline & Oscillatoria & 1 & $1.273,89$ & 1 & $1.273,89$ & 1 & $1.273,89$ & & \\
\hline \multirow[t]{4}{*}{3} & Dinoflagellata: & & & & & & & & \\
\hline & Peridinium & 3 & $3.821,66$ & 5 & $6.369,43$ & 1 & $1.273,89$ & 9 & $11.464,97$ \\
\hline & Gymnodinium & & & 1 & $1.273,89$ & & & & \\
\hline & Protoperidinium & 1 & $1.273,89$ & 6 & $7.643,31$ & 2 & $2.547,77$ & 2 & $2.547,77$ \\
\hline \multicolumn{2}{|c|}{ Jumlah sel/L } & & 21656,07 & & 49681,55 & & 12738,87 & & 28025,48 \\
\hline \multicolumn{2}{|c|}{ Jumlah Jenis } & & 7 & & 11 & & 6 & & 6 \\
\hline \multicolumn{2}{|c|}{ Indeks Keanekaragaman $\left(\mathrm{H}^{\prime}\right)$} & & 1,8439 & & 1,7910 & & 1,6957 & & 1,5620 \\
\hline \multicolumn{2}{|c|}{ Indeks Keseragaman (E) } & & 0,9476 & & 0,7469 & & 0,9464 & & 0,8718 \\
\hline \multicolumn{2}{|c|}{ Indeks Dominansi (D) } & & 0,1696 & & 0,2439 & & 0,2000 & & 0,2521 \\
\hline
\end{tabular}

Sumber : Laboratorium Penguji BBAP Situbondo (2009)

Hasil analisis parameter biologi pada Tabel 5 dan Tabel 6 menunjukkan bahwa pada perairan Klatakan Kecamatan Kendit didapatkan nilai kelimpahan fitoplankton pada kisaran $7.643,33$ - 14012,75sel/L $(11464,98 \pm$ 2751,903035). Jumlah spesies fitoplankton yang ditemukan pada kisaran 4-6 spesies, yang secara keseluruhan didominasi oleh diatom dari jenis Hiroditikon sp. Sedangkan perairan Gelung Kecamatan Panarukan nilai kelimpahan fitoplankton pada kisaran $12.738,87-49.681,55 \mathrm{sel} / \mathrm{L}(28025,4925 \pm$ 15739,91949). Jumlah spesies fitoplankton yang ditemukan pada kisaran 6-11 spesies yang secara keseluruhan didominasi oleh diatom dari jenis Thalasionema sp. dan dinoflagellata dari jenis Protoperidinium sp. Landner (1978) dalam Basmi (2000) menyatakan bahwa berdasarkan kesuburan nutrien, perairan dikategorikan menjadi tiga kondisi yaitu perairan eutrofik (kondisi dengan kandungan nutrien tinggi dimana kualitas perairan mengalami penurunan dengan kelimpahan fitoplankton lebih dari 15.000 ind/L), perairan mesotrofik (kondisi dengan kandungan nutrien sedang dengan kelimpahan fitoplankton 2.000-15.000 ind/L) dan perairan oligotrofik (kondisi dengan kandungan nutrien yang miskindengan kelimpahan fito-plankton 0-2.000 ind/L). Berdasarkan hal ini, maka perairan Gelung Kecamatan Panarukan digolongkan perairan eutrofik sedangkan perairan Klatakan Kecamatan Kendit digolongkan perairan mesotrofik. 
Hasil analisis nilai indeks keanekaragaman plankton di perairan Klatakan Kecamatan Kendit tertinggi terdapat di stasiun $K_{1}$ berkisar 1,5568 dan terendah di stasiun $\mathrm{K}_{3}$ berkisar 0,8856. Sedangkan perairan Gelung Kecamatan Panarukan tertinggi di stasiun $\mathrm{P}_{1}$ berkisar 1,8439 dan terendah di stasiun $\mathrm{P}_{4}$ berkisar 1,5620. Secara keseluruhan nilai indeks keanekaragaman pada perairan Klatakan Kecamatan Kendit berkisar antara 0,8856-1,558, sedangkan perairan Gelung Kecamatan Panarukan berkisar antara 1,5620-1,8430. Struktur komunitas biota di perairan Klatakan Kecamatan Kendit dan perairan Gelung Kecamatan Panarukan dinyatakan moderat (sedang), artinya kondisi struktur komunitas biota di ke dua perairan tersebut mudah berubah dengan hanya mengalami pengaruh lingkungan yang relatif kecil.

$\begin{array}{ccc}\begin{array}{c}\text { Menurut } \\ \text { menjelaskan }\end{array} & \begin{array}{c}\text { Basmi } \\ \text { apabila }\end{array} & \begin{array}{c}(2000), \\ \text { indeks }\end{array}\end{array}$
keanekaragaman kurang dari 1, maka komunitas biota dinyatakan tidak stabil. Tidak stabil artinya komunitas bersangkutan sedang mengalami gangguan faktor lingkungan, misalnya mengalami stress adanya limbah (polutan). Apabila indeks keanekaragaman berkisar antara 1-3, maka stabilitas komunitas biota tersebut adalah moderat (sedang) artinya kondisi komunitas akan mudah berubah hanya dengan mengalami pengaruh lingkungan yang kecil. Misalkan pengaruh polutan, maka struktur komunitas mengarah kepada indeks keanekaragaman kecil $\left(\mathrm{H}^{\prime}<1\right)$, apabila ada hujan karena terjadi pengenceran maka struktur komunitas akan dapat berkembang biak secara normal. Apabila indeks keragaman lebih besar dari 3, maka kondisi struktur komunitas biota stabil artinya kondisi struktur komunitas ditunjang oleh faktor yang prima untuk semua spesies yang hidup dalam habitat yang bersangkutan. Semakin besar nilai indeks keanekaragaman menunjukkan semakin beragamnya kehidupan di perairan tersebut, kondisi ini merupakan tempat hidup yang lebih baik.

Hasil analisis nilai indeks keseragaman plankton pada perairan Klatakan Kecamatan Kendit tertinggi di stasiun $\mathrm{K}_{1}$ berkisar 0,9673 dan terendah di stasiun $K_{3}$ berkisar 0,6388. Sedangkan perairan Gelung Kecamatan Panarukan tertinggi di stasiun $\mathrm{P}_{1}$ berkisar 0,9476 dan terendah di stasiun $\mathrm{P}_{2}$ berkisar 0,7469. Secara keseluruhan nilai indeks keseragaman pada perairan Klatakan Kecamatan Kendit berkisar antara 0,6388-0,9673, sedangkan perairan Gelung Kecamatan Panarukan berkisar antara 0,7469-0,9476. Berdasarkan nilai indeks keseragaman dari ke dua perairan, maka dapat dikatakan jumlah individu pada masing-masing spesies di perairan Klatakan Kecamatan Kendit dan perairan Gelung Kecamatan Panarukan relatif sama atau perbedaannya tidak menyolok.

Basmi (2000) menjelaskan bahwa nilai indeks keseragaman spesies berkisar antara 0-1, bila indeks tersebut mendekati 0 berarti keseragaman antar spesies di dalam komunitas rendah, mencerminkan kekayaan individu yang dimiliki masing-masing spesies sangat jauh berbeda. Sebaliknya bila mendekati 1, berarti keseragaman antar spesies dikatakan relatif merata, atau dengan kata lain jumlah individu pada masing-masing 
spesies relatif sama. Hal ini diperkuat Pirzan dan Pong-Masak (2006) dalam Pirzan dan Pong-Masak (2008) yang menyatakan bahwa apabila keseragaman mendekati nol berarti keseragaman antar spesies di dalam komunitas tergolong rendah dan sebaliknya keseragaman yang mendekati satu dapat dikatakan keseragaman antar spesies tergolong merata atau sama.

Hasil analisis nilai indeks dominansi plankton pada perairan Klatakan Kecamatan Kendit pada masing-masing stasiun berkisar antara 0,2199-0,5537. Sedangkan perairan Gelung Kecamatan Panarukan pada masing-masing stasiun berkisar antara 0,1696-0,2521. Pada umumnya nilai indeks dominansi di perairan Klatakan Kecamatan Kendit dan perairan Gelung Kecamatan Panarukan (untuk stasiun $\mathrm{K}_{1}$, $\mathrm{K}_{2}, \mathrm{~K}_{3}, \mathrm{P}_{1}, \mathrm{P}_{2}, \mathrm{P}_{3}$, dan stasiun $\mathrm{P}_{4}$ ) mendekati 0 , artinya di dalam struktur komunitas yang diamati tidak terdapat spesies yang secara ekstrim mendominasi spesies lainnya, hal ini menunjukkan kondisi struktur komunitas dalam keadaan stabil. Sedangkan indeks dominansi pada stasiun $\mathrm{K}_{4}$ di perairan Klatakan Kecamatan Kendit mendekati 1, menunjukkan bahwa di dalam struktur komunitas yang sedang diamati dijumpai spesies yang mendominasi spesies lainnya.

Basmi (2000) menjelaskan bahwa indeks dominansi spesies dalam suatu komunitas berkisar antara 0-1. Bila indeks dominansi spesies mendekati 0 , berarti di dalam struktur komunitas biota yang diamati tidak terdapat spesies yang secara ekstrim mendominasi spesies lainnya, kondisi struktur komunitas dalam keadaan stabil, kondisi lingkungan cukup prima dan tidak terjadi tekanan ekologis terhadap biota di habitat yang bersangkutan. Sebaliknya bila indeks dominansi spesies mendekati 1 , berarti di dalam struktur komunitas biota yang diamati dijumpai spesies yang mendominasi spesies lainnya, kondisi struktur komunitas dalam keadaan labil, terjadi tekanan ekologis terhadap biota di habitat yang bersangkutan, hal ini mungkin habitat (subhabitat) yang dihuni sedang mengalami gangguan baik yang berupa fisik, kimia maupun biologi. Faktor utama yang mempengaruhi jumlah organisme, keragaman jenis dan dominansi antara lain adanya perusakan habitat alami seperti pencemaran kimia dan organik, serta perubahan iklim (Pirzan dan Pong-Masak, 2006 dalam Pirzan dan Pong-Masak, 2008).

\section{KESIMPULAN}

Berdasarkan hasil pengukuran dan pengamatan di lapangan dan di laboratorium terhadap faktor biofisik perairan di ke dua lokasi penelitian dapat diambil kesimpulan bahwa secara keseluruhan parameter kualitas air di perairan Klatakan Kecamatan Kendit Kabupaten Situbondo lebih layak untuk dijadikan lokasi pengembangan budidaya ikan kerapu dalam keramba jaring apung dibandingkan perairan Gelung Kecamatan Panarukan Kabupaten Situbondo. Namun ada beberapa variabel yang terdapat pada faktor biofisik perairan di ke dua lokasi pengembangan budidaya ikan kerapu tersebut untuk selalu dipantau pengamatannya seperti variabel elevasi pasang surut, tinggi gelombang, kecerahan perairan dan variabel $\mathrm{H}_{2} \mathrm{~S}$. 


\section{UCAPAN TERIMA KASIH}

Pada kesempatan ini penulis mengucapkan terima kasih kepada Prof. Dr. Ir. Johannes Hutabarat, MSc. dan Dr. Ir. Agung Sudaryono, MSc, Prof. Dr. Ir. Sutrisno Anggoro, MS., dan Khrisna Ari Purnama, ST yang telah banyak memberikan dorongan kepada penulis dalam menyelesaikan studi.

\section{DAFTAR PUSTAKA}

Akbar, S dan Sudaryanto, 2002. Pembenihan dan Pembesaran Kerapu Bebek. Penebar Swadaya. Jakarta. 104 hlm.

APHA (American Public Healt Association). 1998. Standard Methods for the Examination of Water and Wastewater. American Public Health Association. Washington, DC. $874 \mathrm{hlm}$.

Basmi, J. 2000. Planktonologi : Plankton Sebagai Indikator Kualitas Perairan. Fakultas Perikanan dan Ilmu Kelautan. Institut Pertanian Bogor.60 hlm.

Boyd, C.E. 1999. Code of Practice for Responsible Shrimp Farming. St.Louis, MO.: Global Aquaculture Alliance.

Dinas Kelautan dan Perikanan Kabupaten Situbondo. 2007-2009. Laporan Evaluasi Pembangunan Kelautan dan Perikanan. Pemerintah Kabupaten Situbondo.

Ditjen Perikanan Budidaya. 2005. Petunjuk Teknis Budidaya Laut Ikan Kerapu (Epinephelus sp. dan Cromileptes altivelis). Direktorat Pembudidayaan. Direktorat Jenderal Perikanan Budidaya. Jakarta. $51 \mathrm{hlm}$.
Dwiyanto, F.S. dan Suriawan, A. 2006. Petunjuk Teknis Budidaya Kerapu di Keramba Jaring Apung. Departemen Kelautan dan Perikanan. Direktorat Jenderal Perikanan Budidaya. Balai Budidaya Air Payau Situbondo. 32 hlm.

Hanggono B. 2007. Manajemen Lingkungan dan Kualitas Air. Disajikan Pada Pelatihan Pembenihan Ikan Kerapu Di BBAP Situbondo tanggal 21-26 Mei 2007. Kerjasama Antara Balai Budidaya Air Payau Situbondo dengan Jafan International Cooperation Agency (JICA). Direktorat Jenderal Peikanan Budidaya Departemen Kelautan dan Perikanan. Situbondo. $120 \mathrm{hlm}$.

LAPAN. 2004. Verifikasi dan Validasi Informasi Berdasarkan Data Penginderaan Jauh Untuk Budidaya Laut. Studi Kasus : Kesesuaian Perairan Budidaya Ikan Kerapu Dengan Menggunakan Keramba Jaring Apung di Kabupaten Situbondo. Pusat Pengembangan Pemanfaatan dan Teknologi Penginderaan Jauh. Deputi Bidang Penginderaan Jauh. Lembaga Penerbangan dan Antariksa Nasional. Jakarta.

MENLH (Menteri Negara Lingkungan Hidup). 2004. Surat Keputusan Menteri Negara Lingkungan Hidup No.KEP-51/MENLH/ 2004 tentang Baku Mutu Air Laut untuk Biota Laut, Lampiran III.

Newel, G.E. and R.C. Newel. 1977. Marine Plankton. London: Hutchintson.

Odum, P.E. 1971. Fundamentals of Ecology. Saunders College Publishing. Rinehart and Winston, Inc. Translation Copyright 1993 by Gadjah Mada University Press. 
Pirzan, A.M. dan P.R. Pong-Masak. 2008.

Hubungan Keragaman Fitoplankton

Dengan Kualitas Air di Pulau

Bauluang, Kabupaten Takalar,

Sulawesi Selatan. Jurnal

BIODIVERSITAS ISSN:

1412-033X. Volume 9, Nomor 3

Juli 2008. Halaman: 217-221.

Sudradjat, A. 2008. Budidaya 23

Komoditas Laut Menguntungkan.

Penebar Swadaya. Jakarta.

$171 \mathrm{hlm}$. 